\title{
Improving SCOBY starter using co-culture of tapai and bakery yeast
}

\author{
AURORA URBAHILLAH ${ }^{1}$, JAY JAYUS ${ }^{2,3}$, NURHAYATI NURHAYATI ${ }^{2,3,4}$ \\ ${ }^{1}$ Graduate School of Biotechnology, Universitas Jember. J1. Kalimantan No. 37, Kampus Tegalboto, Jember 68121, East Java, Indonesia \\ ${ }^{2}$ Center for Development of Advanced Sciences and Technology, Universitas Jember. Jl. Kalimantan No. 37, Jember 68121, East Java, Indonesia \\ ${ }^{3}$ Department of Agricultural Products Technology, Faculty of Agricultural Technology, Universitas Jember. Jl. Kalimantan No. 37, Kampus Tegalboto, \\ Jember 68121, East Java, Indonesia. Tel.: +62-331-321784, `email: nurhayati.ftp@unej.ac.id
}

Manuscript received: 25 June 2021. Revision accepted: 29 September 2021.

\begin{abstract}
Urbahillah A, Jayus J, Nurhayati N. 2021. Improving SCOBY starter using co-culture of tapai and bakery yeast. Biodiversitas 22: 4617-4624. Kombucha is a beverage fermented by a symbiotic bacteria and yeast known as SCOBY (Symbiotic Culture of Bacteria and Yeast). Bacteria and yeast contribute to the formation of organic acids, aroma, taste, and flavor of kombucha. The commercial yeasts used in Indonesian are baker's yeast and tapai yeast. This study was conducted to develop SCOBYco-culture with tapai yeast and baker's yeast and evaluate its activity. The ingredients for the kombucha were cascara, water, and sugar, which were fermented with three formula starters, i.e. original SCOBY $10 \% \mathrm{w} / \mathrm{v}(\mathrm{SN})$, co-culture SCOBY $10 \% \mathrm{w} / \mathrm{v}$ with $0.1 \%$ w/v of baker's yeast (SNR), and coculture SCOBY $10 \% \mathrm{w} / \mathrm{v}$ with tapai yeast $0.1 \% \mathrm{w} / \mathrm{v}$ (SNT). The starter activity was determined based on the OD (Optical Density) value. Yeast screening was carried out on the dominant starter population. Furthermore, morphologically yeast was identified based on colony type, color, and shape of cell. Then yeast was identified by their fermentation profile using API 20C Aux Kit. Isolate A showed white colony with convex elevation and the cell was round-shaped. Colony of isolate B and isolate C were creamy in color and oval cell shaped. The API results revealed that the first isolate was identified as Candida famata, second isolate was Candida krusei, and the third isolate was Candida magnoliae. Three types of fungi were found from SCOBY, namely Mucor sp., Trichoderma sp., and Fusarium sp. Mucor sp. has non-septate hyphae, and round black spores. Trichoderma sp. has septate hyphae, greenish-white spores, and the conidia have the shape of globose to ellipsoidal Fusarium sp. has a mold with septate hyphae, yellowish-white colonies, and the conidia have the shape of obovoid. Bacteria, yeast, and mold present in the medium form a powerful symbiosis for produce metabolites.
\end{abstract}

Keywords: Baker's yeast, cascara, fermentation, kombucha, tapai yeast

\section{INTRODUCTION}

Kombucha is a fermented beverage using symbiotic bacteria and yeast or SCOBY. Due to the symbiosis between bacteria and yeast, kombucha can inhibit the growth of microbial pathogens (Loncar et al. 2013). Kombucha fermentation is carried out for 7-12 days (Chakravorty et al. 2016; Mukadam et al. 2016).

Kombucha cascara was fermented with three variations of starter using SCOBY original $10 \% \mathrm{w} / \mathrm{v}$, co-culture SCOBY $10 \% \mathrm{w} / \mathrm{v}$ with baker's yeast $0.1 \% \mathrm{w} / \mathrm{v}$ and coculture SCOBY $10 \% \mathrm{w} / \mathrm{v}$ with tapai yeast $0,1 \% \mathrm{w} / \mathrm{v}$. SCOBY addition of as much as $10 \% \mathrm{w} / \mathrm{v}$ in accordance with previous studies (Jayabalan et al. 2014; Mukadam et al. 2016). Nursiwi et al. (2018) made a probiotic drink from glutinous tape powder with the addition of Lactobacillus plantarum. Mills et al. (2002) made wine from chardonnay (green-skinned grapes) using $0.1 \%$ yeast.

The interaction between kombucha bacteria and yeast produces various metabolites with interesting bioactivity. Bacteria and yeast are trapped in the biofilm matrix called SCOBY (Marsh et al. 2014; May et al. 2017). SCOBY is a cellulose pellicle consisting of a symbiotic culture of bacteria and yeast. SCOBY is used as an inoculum for kombucha fermentation.

Developing kombucha instead of a multitude of matrixdependent consortia, those specific organisms are unidentified. This is known as the simultaneous presence of yeast and acetic acid bacteria, lactic acid bacteria are not always present (Tran et al. 2020). Villarreal-Soto et al. (2020) investigated the relationship between the microbiota and metabolites of kombucha. Bacteria and yeast interact through cooperative metabolism, contributing to the synthesis and sensory qualities of kombucha. Bacteria and yeast use sugar as a substrate to grow and produce organic acids (Chakravorty et al. 2016; Quiao-Won and Franco 2018). Yeast is responsible for the enzymatic hydrolysis of sucrose into glucose and fructose; glucose and fructose are converted into ethanol and $\mathrm{CO}_{2}$, while bacteria convert glucose into gluconic acid and ketogluconic acid, and fructose into acetic acid (Loncar et al. 2014). In addition, yeast also contributes to forming aroma, taste, and flavor of kombucha (Marsh et al. 2014).

Yeast has been widely used as a starter for fermented beverages. Zou et al. (2019) performed co-culture yeast and lactic acid bacterium on the fermentation of lychee juice. Yeast in co-culture fermentations is often used in the industry to enrich the aromatic profile. Wine is a drink fermented by yeast starters (Eder et al. 2018), kefir (Gul et al. 2018), cheka, borde, and keribo (Hotessa and Robe 2020). Non Saccharomyces yeast isolated from kombucha starter was used to make low-alcohol beer (Bellut et al. 2018).

Otherwise, commercial yeast can be obtained from baker's yeast and tapai yeast. Other research has reported that tapai yeast contains molds, such as Rhizopus oryzae, 
Monilesaurus rouxii, Aspergillus orzae, Saccharomyces cervisiae, Endomycopsis burtonii, Pediococcus pentosaceus, Hansenula anomala, Candida krusei, Candida magnoliae (Chiang et al. 2006; Rahman et al. 2018), whereas baker's yeast contains Saccharomyces cerevisiae (Karki et al. 2017). Kumoro et al. (2012) used baker's yeast in the production of jackfruit wine. But there have been no studies on adding yeast from outside coculture with SCOBY microbes. While the species diversity and kinetics during kombucha fermentation have been reported by Mukadam et al. (2016) and Tran et al. (2020). The aim of this study is to formulate a co-culture SCOBY starter with tapai and baker's yeast and to evaluate its activity.

\section{MATERIALS AND METHODS}

\section{Formulation of SCOBY co-culture}

Formulation of SCOBY co-culture used tapai yeast and baker's yeast that were purchased from the Jember local market at East Java Province-Indonesia. The substrate was made from cascara tea $(1 \% \mathrm{w} / \mathrm{v})$ purchased from Ijen Bondowoso, East Java-Indonesia with added sucrose $10 \%$ $(\mathrm{w} / \mathrm{v})$. Then boiled and stir for 5 minutes. The substrate was filtered, then cooled to $40^{\circ} \mathrm{C}$. Furthermore, the substrate was put into a glass dispenser (glass jar with a faucet). Then the substrate was inoculated with developed starter i.e. SCOBY native (SN), consortium of SCOBY native + tapai yeast (SNT), new consortium of SCOBY native + baker's yeast (SNR). Consortium of SCOBY was formulated by adding $0.1 \%(\mathrm{w} / \mathrm{v})$ baker's yeast into $10 \%$ SCOBY (w/v) as SNR, or by adding $0.1 \%(w / v)$ tapai yeast into $10 \%(\mathrm{w} / \mathrm{v}) \mathrm{SCOBY}$ as SNT. Fermentation was carried out in the glass dispenser and not exposed to direct sunlight for 21 days, covered with a clean cloth, resulting in a coculture starter.

\section{Determination of SCOBY co-culture population}

The SCOBY co-culture population was calculated to determine the viability of SCOBY co-culture i.e. bacteria, yeast and mold populations. SCOBY co-culture population was calculated from two serial dilutions by the BAM method (Dalu et al. 2019). The bacteria were grown on De Mann Rogosa Sharpe Agar by pour plate method (MRSAMerck 1.10660, Germany). The yeast and mold were grown on Malt Extract Agar and Potato Dextrose Agar media, respectively (MEA-Merck 1.05398, Germany and PDA-Merck 1.10130, Germany). The dilution for plating was until $10^{-4}$. The viability of the microorganisms was calculated using the formula in Bacteriological Analytical Manual (BAM).

\section{$\mathrm{N}:\{\Sigma \mathrm{C} /[(1 \times \mathrm{n} 1)+(0.1 \times \mathrm{n} 2) \times(\mathrm{d})]\}$}

Where; N: number of colonies; $\Sigma \mathrm{C}$ : total number of counted colonies; $\mathrm{n} 1$ : number of plates in dilution $1 ; \mathrm{n} 2$ : number of plates in dilution 2; d: dilution rate.

\section{Morphological identification of yeast and mold}

Morphological characteristics of yeast colonies included color and shape of colony, and cell shape. Morphological characteristics of mold included hyphae color, spore color, septa or non-septa hyphae, and the shape of conidia (Astriani et al. 2018; Akroman et al. 2019). Observations were made macroscopically and microscopically under XSZ-107 binoculars with a magnification of $1000 x$ for yeast and 400x for mold.

\section{Identification of yeast strain from SCOBY co-culture using API 20C-Aux kit}

Yeast was identified based on fermentation profile using API 20C-Aux kit, consisting of 20 wells were wells first as a negative control $(\mathrm{O})$, pitting both as a positive control containing glucose (GLU), and 18 tubes were glycerol (Gly), calcium 2-keto gluconate (2KG), arabinose (ARA), xylose (XYL), adonitol (ADO), xylitol (XLT), galactose (GAL), inositol (INO), sorbitol (SOR), methyl$\alpha \mathrm{D}$-glucopyranoside (MDG), N-acetyl-Glucosamine (NAG), Cellobiose (CEL), lactose (LAC), maltose (MAL), saccharose (SAC), trehalose (TRE), melezitose (MLZ) and raffinose (RAF) (Nurhayati et al. 2018). Observations pattern of fermentation after 24 hours was based on whether or not the substrate turbid on pitting. If the media becomes cloudy, it means a positive reaction and if the media was clear (not cloudy), it means negative reaction. The results were collected and acquired on 7 digit biocode. The code was compared with the identification book or confirm on apiwebTM (https: //apiweb.biomerieux.com//) to identify the type of yeasts.

\section{Fermentation process of kombucha}

Analysis of $\mathrm{pH}$ value

The $\mathrm{pH}$ value of kombucha was analyzed every 2 days for 8 days using a Horiba $\mathrm{pH}$ meter F-51-HR4659. The $\mathrm{pH}$ meter was first calibrated using 7.0 and 4.0 buffers. The $\mathrm{pH}$ meter was directly inserted into the kombucha for readings.

\section{Analysis of acid total}

A 2-3 drops of phenolphthalein were added to $50 \mathrm{ml}$ of kombucha. Then it was titrated with $0.1 \mathrm{~N} \mathrm{NaOH}$ solution until the color changed to pink color. Total titratable acid (TTA) was expressed as percent of acetic acid. TTA has calculated the following formula:

$$
\% \text { total acid: } \frac{\mathrm{mL} \text { NaOH x N NaOH x BM x FP }}{m L \text { sample } x 1000} \times 100 \%
$$

Where; Normality (N) NaOH: $0.1 \mathrm{~N}$; Molecular Weight (BM) of acetic acid: 90; Dilution Factor (FP): 1.

\section{Analysis of alcohol}

Alcohol content was measured using the Conway method. Samples of $1 \mathrm{~mL}(\mathrm{~A}), 2 \mathrm{~mL} \mathrm{KCrO}_{7}$ (B), and $1 \mathrm{~mL}$ $\mathrm{Na}_{2} \mathrm{CO}_{3}(\mathrm{C})$ were put on a Conway chamber. The Conway chamber was shaken to mix $\mathrm{A}$ and $\mathrm{C}$ solution, then the chamber was covered and allowed to stand/incubate for 120 minutes. After incubation, $2 \mathrm{~mL}$ of distilled water was added into $\mathrm{K}_{2} \mathrm{CrO}_{7}(\mathrm{C})$ and measure the absorbance was at 
$605 \mathrm{~nm}$ wavelength. Total alcohol obtained from the sample absorbance measurements was plotted with the standard curve alcohol made using 100, 200, 300, 400, 500, 600, 700, 800, 900, $1000 \mu \mathrm{l}$ ethanol. Absorbance results, then the standard curve equation is calculated. The linearity equation is $\mathrm{y}$ : bx $+\mathrm{a}$. The formula alcohol content was computed using the following equation:

Total alcohol $(\%)=\frac{\text { (absorbance sample }- \text { absorbance blank })-b}{a} \times 100 \%$

\section{Analysis of microbial growth during kombucha fermentation}

Microbial growth was observed based on turbidity change using optical density (OD) methods. Samples placed in a $1.5 \mathrm{~mL}$ cuvette were observed using a spectrophotometer (Hitachi U-2900) at a wavelength of $620 \mathrm{~nm}$.

\section{RESULTS AND DISCUSSION}

\section{Morphological characteristics of yeast SCOBY co- culture}

The most dominant yeast was isolated and identified. Three yeast isolates from kombucha cascara were i.e. isolate $\mathrm{A}, \mathrm{B}$, and $\mathrm{C}$. They have difference in colony color and cell shape (Table 1).

Colony of isolate A had round form with convex elevation and white cloud color. Colony of isolate B and C had round and creamy with convex elevation. The form of yeast cells is shown in Figure 1.

Figure 1 showed that isolate $\mathrm{A}$ has round and ovalshaped cells. Isolate B is yeast has round-shaped cells, while isolate $\mathrm{C}$ has oval-shaped cells. The cells of yeast isolates were of different sizes. The life cycle of yeast is complex and consists of cellular stages that include different shapes of cells (Knop 2011). Generally, the shape of yeast cells may vary from circular, spherical, oval, elliptical, elongated, rectangular, dumb-bell shaped to triangular (Hyun and Lee 2014; Dunkler et al. 2021).

\section{Fermentation profile of yeast co-culture SCOBY}

Result of the fermentation profile of yeast isolates A, B, and $\mathrm{C}$ can be seen in Table 2. The three yeast strains showed that different responses to ferment the substrate.

All yeasts were able to ferment certain sugars as a carbon source. The result showed that yeast $\mathrm{A}$ isolates can ferment some sugars i.e D-raffinose, D-melezitose, Dtrehalose, D-saccharose, D-maltose, D-cellobiose, Nacetyl-glucosamine, methyl-aD-glucopyranoside, Dsorbitol, inositol, D-galactose, adonitol, L-arabinose, calcium 2-keto-gluconate, glycerol, and D-glucose. After confirmation on API web, isolate A was identified as Candida famata (99.6\%). The colony of C. famata is white in color with elevation convex and round-shaped cells (Santra et al. 2014). Candida famata is a yeast with high osmotolerance, and can be found in kombucha (Dmytruk and Sibirny 2012). This yeast was acid-tolerant that dominated during kombucha fermentation. Rosca et al. (2015) reported that $C$. famata can synthesize volatile compounds such as acetaldehyde and diacetyl during alcoholic fermentation.

Table 1. Morphological characteristic of yeast from kombucha cascara

\begin{tabular}{|c|c|c|c|}
\hline \multirow[b]{2}{*}{$\begin{array}{l}\text { Code of } \\
\text { isolates }\end{array}$} & \multicolumn{3}{|c|}{ Morphological characteristics } \\
\hline & Shape of colony & $\begin{array}{c}\text { Color of } \\
\text { colony }\end{array}$ & $\begin{array}{l}\text { Shape } \\
\text { of cell }\end{array}$ \\
\hline A & Round, with convex elevation & $\begin{array}{l}\text { White } \\
\text { cloud }\end{array}$ & Round \\
\hline B & Round, with con & Creamy & Oval \\
\hline $\mathrm{C}$ & Round, with convex elevation & Creamy & Oval \\
\hline
\end{tabular}

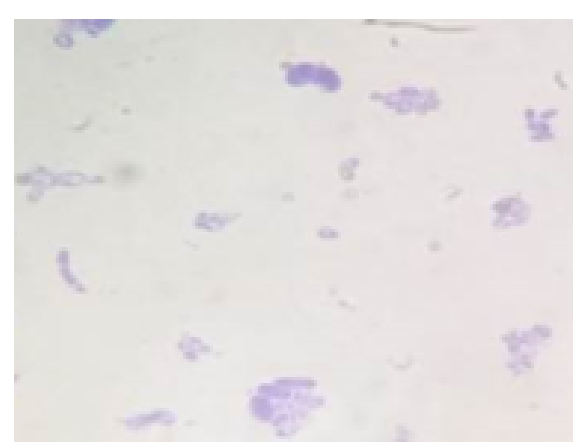

A

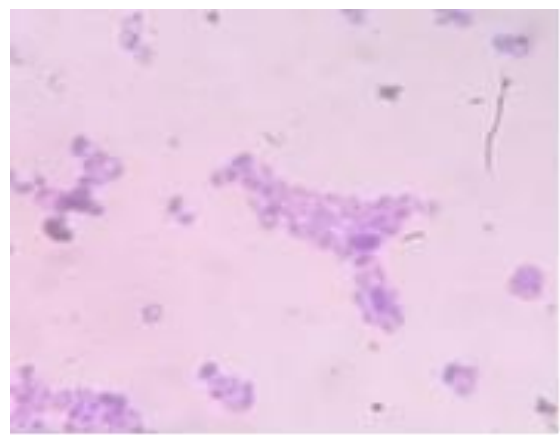

B

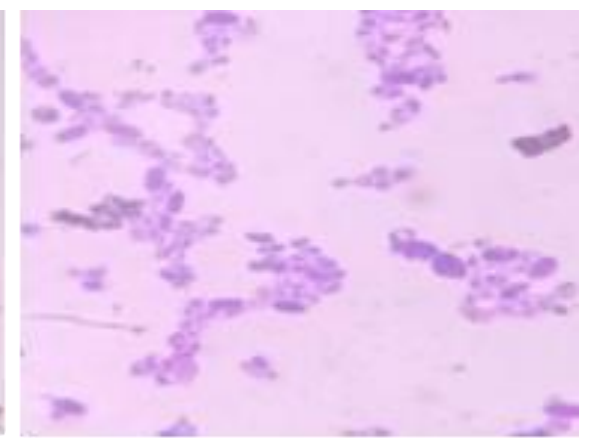

C

Figure 1. Morphological characteristics of yeast isolated from SCOBY co-culture 
Table 2. Fermentation profile of yeast kombucha cascara using KIT API 20 C Aux

\begin{tabular}{|c|c|c|c|c|c|c|c|c|c|c|c|c|c|c|c|c|c|c|c|c|c|c|c|}
\hline 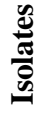 & 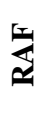 & $\stackrel{N}{\Sigma}$ & 일 & $\underset{\sim}{\mathscr{U}}$ & $\sum$ & $\underset{\smile}{U}$ & 牙 & $\underset{\zeta}{Z}$ & 光 & ํㅡㅇ & $\stackrel{0}{\underline{Z}}$ & ङ & $\ddot{E}$ & 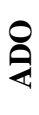 & $\nexists$ & 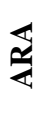 & $\frac{U}{N}$ & $\sqrt{3}$ & Ð & 0 & $\sum^{2}$ & $\begin{array}{c}\text { Identified } \\
\text { species }\end{array}$ & $\begin{array}{c}\text { Identifi- } \\
\text { cation } \\
(\%)\end{array}$ \\
\hline $\mathrm{A}$ & + & + & + & + & + & - & + & + & + & + & + & + & + & + & + & + & + & + & + & - & - & C. famata & 99.6 \\
\hline B & - & - & - & - & - & - & - & + & - & - & - & - & - & - & - & - & - & + & + & - & - & C. krusei & 42.8 \\
\hline $\mathrm{C}$ & + & - & - & + & - & - & - & - & - & & - & - & - & - & - & - & - & + & + & - & - & C. magnoliae & 38.8 \\
\hline
\end{tabular}

Note: +: assimilated carbon (turbid),-: unassimilated carbon (not turbid), GLU: D-glucose; Gly: glycerol; 2KG: calcium 2-ketogluconate; ARA: L-arabinose; XYL: D-Xylose; ADO: adonitol; XLT: xylitol; GAL: D-galactose; INO: inositol; SOR: D-sorbitol, MDG: methyl-aD-glucopyranoside; NAG: N-acetyl-glucosamine; CEL: D-celliobiose; LAC: D-lactose (bovine origin); MAL: Dmaltose; SAC: D-saccharose (sucrose); TRE: D-trehalose; MLZ: D-melezitose; RAF: D-raffinose; H/PH: hyphae/pseudohyphae

Yeast B isolate can ferment substrate $\mathrm{N}$-acetylglucosamine, glycerol, and D-glucose. The identification results reported that isolate B was Candida krusei (42.8\%). Yadav et al. (2012) reported that $C$. krusei has white color colony with round-oval shape, and cell is round. C. krusei is commonly found in fruits and appear in the kefir fermentation (Yusuf et al. 2020). C. krusei has a role in cocoa fermentation to develop the aroma of chocolate and remove the bitter taste in seeds (Jespersen et al. 2005; Lagunes et al. 2007). C. krusei was also successfully identified in kombucha (Mukadam et al. 2016). Yadav et al. (2012) reported that $C$. krusei contributes to the formation of flavor. $C$. krusei and C. magnoliae were reported to appear in tapai yeast (Chiang et al. 2006). Yeast $\mathrm{C}$ isolate can ferment substrate D-raffinose, D-saccharose, glycerol, and D-glucose. API web results showed yeast C isolate was identified as Candida magnoliae (38.8\%). Jimoh et al. (2012) reported that $C$. magnoliae has creamy color colony and oval shape cell. $C$. magnoliae is one of the fructophilic yeasts (Kim et al. 2013). C. magnoliae is used to produce low-alcohol fermented beverages (Medeiros 2014). C. magnoliae is able to consume fructose faster than other sugars and synthesize organic acids and sugar alcohols such as erythritol, mannitol, and glycerol (Yu et al. 2008).

\section{Morphological characteristics of mold SCOBY co- culture}

Molds were isolated from SCOBY then identified based on their colony/hyphae and spore color, sporangium and the shape of conidia (Table 3 ).
Isolate F1 had a yellowish-white color colony, nonseptate hyphae, spores were round, black and yellowishwhite color, and abundant production of conidia. (Figure 2 A). Based on these characteristics, the fungus was identified as Mucor sp. (Ziaee et al. 2016). Mucor sp. is commonly found in wine fermentation. Mucor sp. is commonly found in instant dry yeast for the fermentation of rice wine (Chay et al. 2017). Dewi and Aziz (2011) revealed that Mucor sp. was identified in tapai yeast. Mucor sp. is also used for the fermentation of sufu (soy cheese) (Cheng et al. 2009; Edeghor et al. 2016). Isolate F2 was molds cream have a hint of green color of the colony, septate hyphae, had conidiophore as a sporangium, and globose to ellipsoidal in conidia shape (Figure 2B). Based on the characteristics, the fungus was identified as Trichoderma sp. (Filizola et al. 2019). Trichoderma sp. has been reported to produce cellulose and can live in acidic conditions (Kuhad et al. 2011).

Table 3. Morphological characteristic of fungi from kombucha cascara

\begin{tabular}{cllll}
\hline \multirow{2}{*}{$\begin{array}{c}\text { Isol } \\
\text { ates }\end{array}$} & Colony color & Sporangium & Hyphae & $\begin{array}{c}\text { Conidia } \\
\text { shape }\end{array}$ \\
\hline F1 & Yellowish-white & Round & $\begin{array}{l}\text { Non- } \\
\text { septate }\end{array}$ & Absent \\
F2 & $\begin{array}{l}\text { Cream with a hint } \\
\text { of green color }\end{array}$ & Conidia & Septate & $\begin{array}{l}\text { Globose to } \\
\text { ellipsoidal }\end{array}$ \\
F3 & Yellowish-white & Conidia & Septate & Obovoid \\
\hline
\end{tabular}

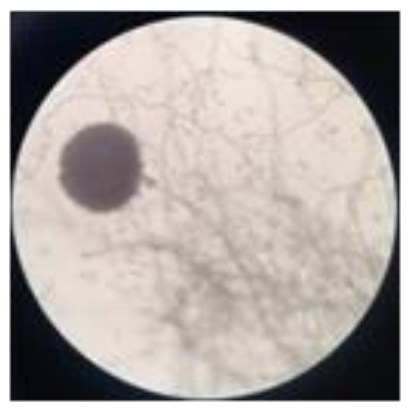

A

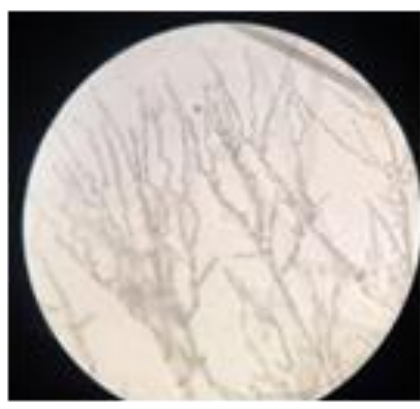

B

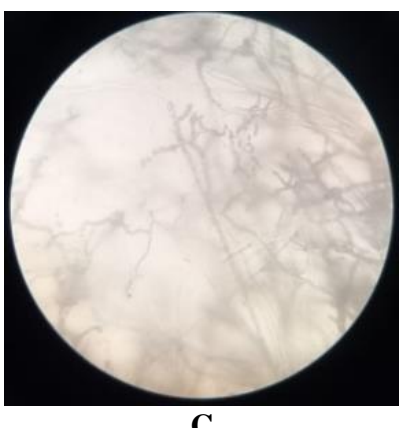

C

Figure 2. Morphological characteristic of molds: isolate F1 (A), isolate F2 (B), isolate F3 (C) 
Isolate F3 was yellowish-white color colony, septate hyphae, and obovoid in conidia shape (Figure 2.C). Based on these characteristics, isolate F3 was identified as Fusarium sp (Valencia and Meitiniarti 2017). Fusarium sp. is capable of producing ethanol (Anasontzis et al. 2016). Fusarium sp. is also found in the traditional fermented beverage from Ghana made of Pennisetum glaucum called solom.

\section{Microbial population of SCOBY co-culture}

Microbial population of SCOBY co-culture was determined using pour plate agar on MRSA, MEA and PDA media. Other research reported that SCOBY contains a mixture of bacteria and yeast (Wistiana and Zubaidah 2015) and mold that can form biofilm (Chakravorty et al. 2016). Microbial population was shown in Table 4.

Results of microbial population showed that the biofilm of the new consortium from the co-culture of SCOBY with tapai yeast and baker's yeast had a higher microbial population than kombucha liquid (Table 4). This is due to microbial trapping (immobilization) in the biofilm by secondary microbial metabolites cellulose (Yaoa et al 2011). Biofilm is commonly used as a starter for subsequent kombucha fermentation. According to Loncar et al. (2014), the ability of bacteria in kombucha starters to synthesize cellulose during fermentation causes parts of microbial cells to be trapped in cellulose webs. This is in line with the opinion of Gullo et al. (2018), which states that the formation of cellulose by bacteria can trap microbes into the biofilm layer. The yeast content in kombucha cascara has the highest microbial population. The total yeast obtained was 5.03-5.82 CFU/mL on day 8 . This is in accordance with research Tran et al. (2020), which states that yeast is the dominant microbe in kombucha.

\section{pH value of kombucha cascara with SCOBY co-culture}

The $\mathrm{pH}$ value indicates kombucha cascara was acidic in nature. Acidity is an essential parameter in fermented beverages because it affects taste and aroma (Tomovska et al. 2016; Rizal et al. 2020). The pH value of -kombucha cascara ranged from 2.6 to 5.9 (Figure 3).

The $\mathrm{pH}$ value of kombucha cascara was observed every two days. The result showed that $\mathrm{pH}$ was significantly decreased $(\alpha<0.05)$ during kombucha cascara fermentation. This is due to the reshuffle of sucrose into alcohol by yeast, then the alcohol is converted to other organic acids by acetic bacteria. Acid release protons (i.e., hydrogen ions, $\mathrm{H}+$ ) resulting in the production of stronger acids (Sawab et al. 2017). A decrease in $\mathrm{pH}$ value was recorded during 3 days of fermentation and may reach from 2.81 to 2.6 after 10 days of fermentation (Neffe-Skocińska et al. 2017).

\section{Acid total of kombucha cascara SCOBY co-culture}

The acid total of kombucha cascara SCOBY co-culture ranged from 0.09 to 1.1 (Figure 4). During fermentation, acid total increased to $1.1 \%$ after 8 days of fermentation. Chakravorty et al. (2016) reported that main organic acid in the kombucha is acetic acid. The data showed that three
SCOBY starters were not found to be significant $(\alpha<0.05)$ for acid total.

Yeast and bacteria cooperate in the production of organic acids. Yeast converts the sucrose into alcohol and stimulates the growth of bacteria to convert alcohol into organic acids. This event is repeated until the substrate is exhausted (Pratiwi et al. 2012). Total acid of kombucha cascara with starter SNT (new consortium of SCOBY native + tapai yeast) and kombucha cascara with starter SNR (new consortium of SCOBY native + baker's yeast) were higher than sample kombucha cascara with starter SN (SCOBY native). The addition of yeast from baker's yeast and tapai yeast allows competition in utilizing food sources. Bacteria will compete with yeast for the available carbon source to synthesize into alcohols and organic acids.

The alcohol value of sample kombucha cascara with starter SNT (new consortium of SCOBY native + tapai yeast) and sample with starter SNR (new consortium of SCOBY native + baker's yeast) were higher than sample kombucha cascara with starter SN (SCOBY native). Addition of yeast from the outside results in rapid conversion of alcohol. The presence of Saccharomyces cerevisiae converts sugar into alcohol and stimulate the growth of Acetobacter xylinum to convert alcohol into acetic acid. Then acetic acid stimulates the growth of S.cerevisiae to produce ethanol. This synergistic growth continues until the substrate is exhausted (Chu and Chen 2006; Senne de Oliveira Lino et al. 2021). Villarreal-Soto et al. (2018) also reported that during kombucha fermentation, yeast produces metabolite that is useful for stimulating bacterial growth.

\section{Alcohol content of kombucha cascara SCOBY co-culture}

The alcohol content of kombucha cascara ranged from 1.2 to $2.39 \%$ (Figure 5). Tran et al. (2020) explain that alcohol amounted to $1-2 \%$ is the threshold flavor and aroma kombucha. The alcohol value of kombucha cascara was not significant $(\alpha<0.05)$ in all treatments.

During fermentation, the alcohol of kombucha cascara increased and then decreased. Total alcohol content of kombucha cascara with SCOBY native (SN) starter increased by $0.15 \%$ on the $4^{\text {th }}$ day and then decreased on the $8^{\text {th }}$ day by $0.48 \%$. It was also observed that kombucha cascara fermented using the new consortium SCOBY native with baker's yeast (SNR) increased the total alcohol by $0.52 \%$ on day 4 and decreased on day 8 by $0.93 \%$. SCOBY native with yeast tapai (SNT) increased on day 4 by $0.26 \%$, then decreased on day 8 by $0.76 \%$.

Table 4. Microbial population of SCOBY co-culture

\begin{tabular}{lccc}
\hline \multirow{2}{*}{ SCOBY co-culture } & \multicolumn{3}{c}{ Microbial populasi $\left(\log _{\mathbf{1 0}}\right.$ cfu/mL) } \\
\cline { 2 - 4 } & BAL & Yeast & Mold \\
\hline Liquid native (SN) & $3.56 \pm 0.12$ & $5.03 \pm 0.09$ & $3.89 \pm 0.05$ \\
Liquid-SNT & $3.58 \pm 0.09$ & $5.26 \pm 0.09$ & $3.94 \pm 0.04$ \\
Liquid-SNR & $3.41 \pm 0.15$ & $5.35 \pm 0.10$ & $4.06 \pm 0.05$ \\
Biofilm native (SN) & $3.81 \pm 0.11$ & $5.40 \pm 0.11$ & $4.02 \pm 0.10$ \\
Biofilm-SNT & $3.69 \pm 0.07$ & $5.59 \pm 0.09$ & $4.12 \pm 0.11$ \\
Biofilm-SNR & $3.76 \pm 0.34$ & $5.82 \pm 0.11$ & $4.23 \pm 0.10$ \\
\hline
\end{tabular}


Changes in the value of alcohol indicated kombucha starter activity. The formation of organic acids causes the alcohol of kombucha cascara to decrease. Mahulette and Astuti (2020) explained that yeast produces alcohol by synthesizing invertase and zymase enzymes. The invertase enzyme is secreted by yeast to break down sucrose either in the media, namely cascara, or additional sucrose to form glucose and fructose. These simple sugars are then reacted with zymase enzymes to produce alcohol.

\section{The microbial growth of SCOBY co-culture}

The microbial growth of SCOBY Co-Culture was determined based on changes in the turbidity level of kombucha. The OD value of kombucha cascara ranged from 0.1 to $0.7 \mathrm{~nm}(\alpha<0.05)$ (Figure 6).

The cell density test using the spectrophotometric method measures microbial cells' absorbance or OD (optical density). Figure 4 shows that on $2^{\text {nd }}$ and $4^{\text {th }}$ day, kombucha cascara with native SCOBY starter (SN) increased to $0.53 \mathrm{~nm}$ and $0.76 \mathrm{~nm}$, then decreased to 0.67 on $6^{\text {th }}$ day, and the absorbance remained constant for $8^{\text {th }}$ day. Unlike kombucha samples fermented using the new consortium SCOBY native + tapai yeast (SNT), and new consortium SCOBY native + baker's yeast (SNR), each increased from day 2 to day 6, i.e. 0.33-0. $69 \mathrm{~nm}$ and 0.35$0.64 \mathrm{~nm}$. On $8^{\text {th }}$ day the two samples showed decreasing absorbance i.e. $0.63 \mathrm{~nm}$ and $0.53 \mathrm{~nm}$.

The increase in microbial growth in logarithmic phase occurs on 2-6 days of fermentation. Figure 6 showed that microbial growth decreased after 6 days of fermentation. Sugar in the substrate was used as carbon source for microbial growth. Wistiana and Zubaidah (2015) reported that a wide series of metabolites can inhibit or slow microbial growth.

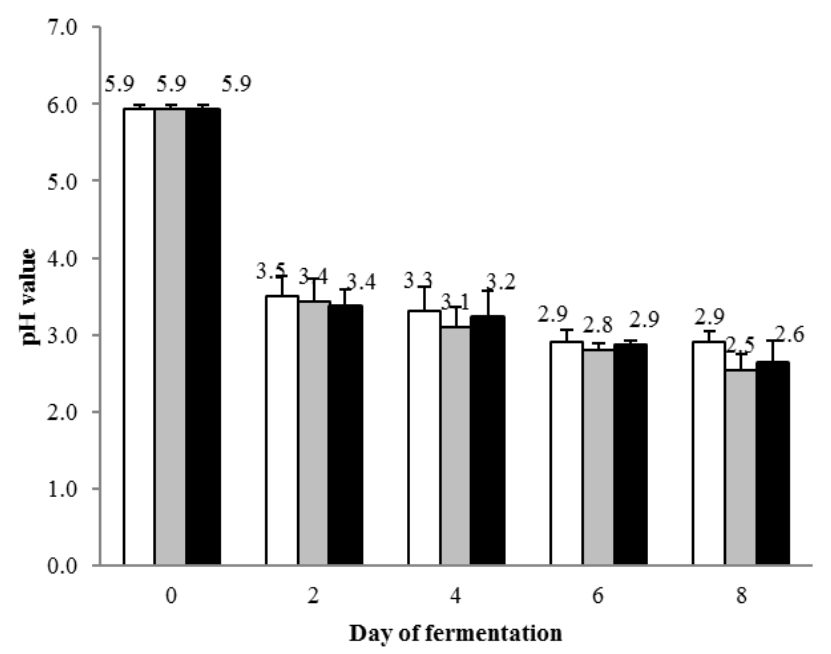

Figure 3. The $\mathrm{pH}$ value of kombucha cascara with SCOBY native/SN ( $\square$ ), new consortium of SCOBY native + tapai yeast /SNT ( $\square$ ), new consortium of SCOBY native + baker's yeast /SNR (ם)

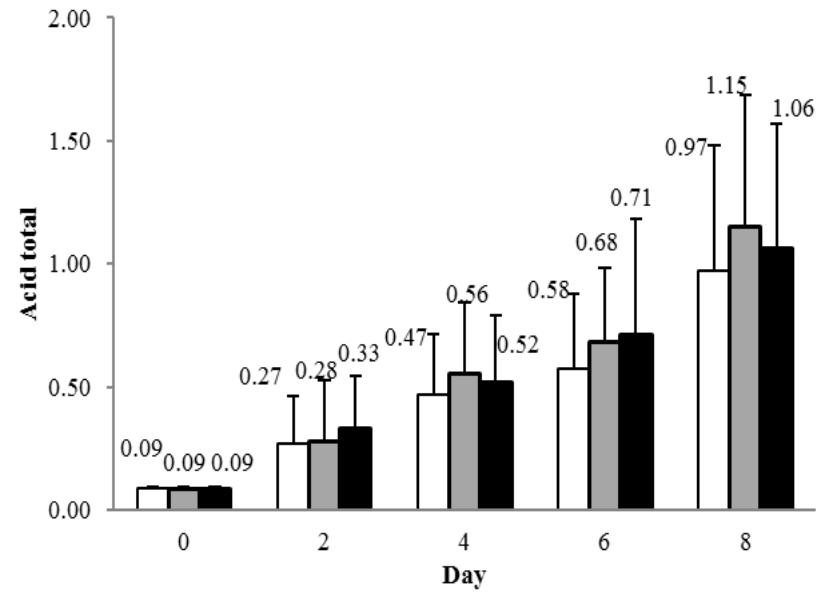

Figure 4. Acid total of kombucha cascara with SCOBY native/SN ( $\square$ ), a new consortium of SCOBY native + tapai yeast /SNT ( $\square$ ), new consortium of SCOBY native + baker's yeast /SNR (ם)

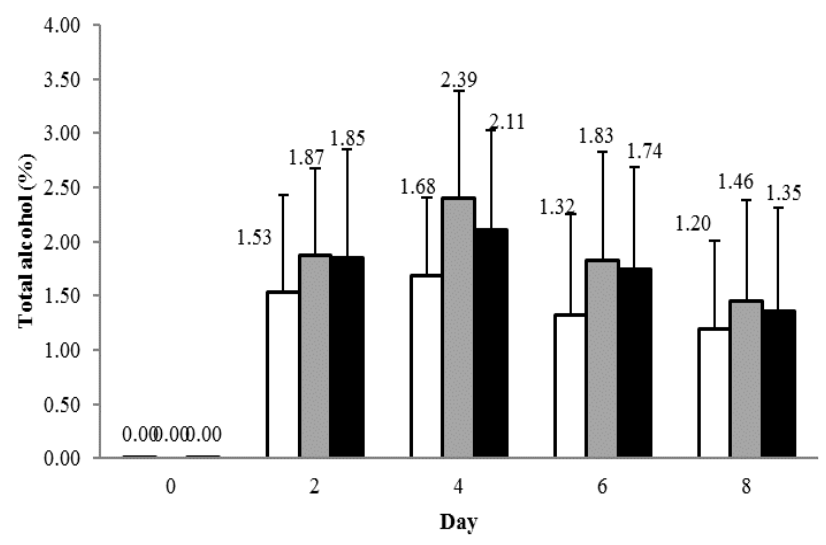

Figure 5. Alcohol content of kombucha cascara with SCOBY native//SN $(\square)$, a new consortium of SCOBY native + tapai yeast /SNT ( $\square$ ), new consortium of SCOBY native + baker's yeast /SNR (

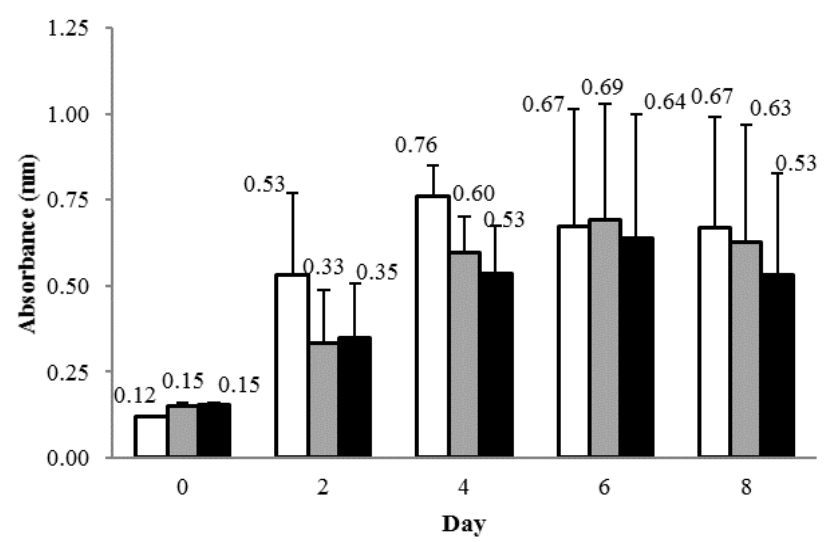

Figure 6. Optical density of kombucha cascara with SCOBY native//SN ( $\square$ ), a new consortium of SCOBY native + tapai yeast /SNT ( $\square$ ), new consortium of SCOBY native + baker's yeast /SNR (ם) 
Kombucha cascara SCOBY co-culture was formulated by adding $0.1 \%$ of the baker's yeast or tapai yeast to the $10 \%$ of native SCOBY. Three yeasts were isolated from the SCOBY co-culture, namely Candida famata, Candida krusei, and Candida magnoliae. The molds were isolated from the SCOBY co-culture, namely Mucor sp., Trichoderma sp. and Fusarium sp. Kombucha cascara fermentation was optimized during 6 days of fermentation. The $\mathrm{pH}$ value and TTA were decreased up to 2.8 for $\mathrm{pH}$ value and $1.1 \%$ for TTA. The alcohol content can reach up to $2 \%$ during kombucha cascara fermentation. In future research, SCOBY co-culture can formulate with other substrates like tropical fruits to prepare kombucha.

\section{ACKNOWLEDGEMENTS}

The authors would like to thank the Minister of Education and Culture, Republic of Indonesia for funding this research by Magister Research Programme 2020 and Accerelated Professor Grant 2021. We thank Astriani for her assistant during this research.

\section{REFERENCES}

Akroman R, Nurhayati, Sony S, Jayus. 2019. Phenotypic and genotypic characteristics of exopolysaccharide producing fungi as a source of food additives. Biodiveristas 20 (9): 2468-2474. DOI: 10.13057/biodiv/d200906

Anasontzis GE, Elisavet K, Silas G, Villas-Boâs, Dimitris GH, Paul C. 2016. Metabolic engineering of Fusarium oxysporum to improve its ethanol-producing capability. Front Microbiol 7: 632. DOI: 10.3389/fmicb.2016.00632

Astriani, Diniyah N, Jayus, Nurhayati. 2018. Phenotypic identification of indigenous fungi and lactic acid bacteria isolated from' Gatot' an Indonesian fermented food. Biodiversitas 19 (3): 947-954. DOI: 10.13057/biodiv/d190325

Bellut K, Maximilian M, Martin Z, Mathias H, Fritz J, David PDS, Luk D, Kieran ML, Emanuele Z, Elke KA. 2018. Application of nonSaccharomyces yeasts isolated from Kombucha in the production of alcohol-free beer. Fermentation 4 (66): 1-19. DOI: 10.3390/fermentation4030066

Chakravorty S, Semantee B, Antonis C, Writachit C, Debanjana B, Ratan G. 2016. Kombucha tea fermentation: Microbial and biochemical dynamics. Int $\mathrm{J}$ Food Microbiol 220: 63-72. DOI: 10.1016/j.ijfoodmicro.2015.12.015

Chay C, Dizon EI, Elegado FB, Norng C, Hurtada WA, Raymundo LC. 2017. Isolation and identification of mold and yeast in medombae, a rice wine starter culture from Kompong Cham Province, Cambodia. J Food Res 1 (6): 213-220. DOI: 10.26656/fr.2017.6.101

Cheng Y, Hu Q, Li-Te L, Masayoshi S, Li-Jun Y. 2009. Production of Sufu, a traditional Chinese fermented soybean food, by fermentation with Mucor flavus at low temperature. Food Sci Technol Res 15 (4): 347-352. DOI: 10.3136/fstr.15.347

Chiang YW, Chye FY, Ismail MA. 2006. Microbial diversity and proximate composition of tapai, A Sabah's fermented beverage. Malays J Microbiol 2 (1): 1-6. DOI: 10.21161/mjm.210601

Chu, Sheng Che S, Chen C. 2006. Effects of origins and fermentation time on the antioxidant activities of Kombucha. Food Chem 98 (3): 502 507. DOI: 10.1016/j.foodchem.2005.05.080

Dalu KCA, Nurhayati, Jayus. 2019. In vitro modulation of fecal microflora growth using fermented "Pisang Mas" banana and red guava juices. Curr Res Nutr Food Sci 7 (2): 449-456. DOI: 10.12944/crnfsj.7.2.14

Dewi RS, Aziz S. 2011. Isolasi Rhizopus oligosporus pada beberapa inokulum tempe di Kabupaten Banyumas. Molekul 6 (2): 93-104. DOI: 10.20884/1.jm.2011.6.2.97. [Indonesian]
Dmytruk KV, Sibirny AA. 2012. Candida famata (Candida flareri). Yeast 29 (11): 453-458. DOI: 10.1002/yea.2929

Dünkler A, Marcin L, Jan-michael K, Joachim N, Thomas G, Andrew B. G, Nils J. 2021. Type V myosin focuses the polarisome and shapes the tip of yeast cells. J Cell Biol 220 (5): e202006193. DOI: 10.1083/jcb.202006193

Edeghor U, Lennox J, Agbo BE, Aminadokiari D. 2016. Bread fermentation using synergistic activity between lactic acid bacteria (Lactobacillus bulgaricus) and baker's yeast (Saccharomyces cerevisiae). Pak J Food Sci 26 (1): 46-53.

Eder M, Isabelle S, Claire B, Carole C, Jean-Luc L, Sylvie D. 2018. QTL mapping of volatile compound production in Saccharomyces Cerevisiae during alcoholic fermentation. BMC Genom 19 (166): 119. DOI: $10.1186 / \mathrm{s} 12864-018-4562-8$

Filizola PRB, Marcos ACL, Souza AF, Iwanne LC, Delson L, Galba MC. 2019. Biodiversity and phylogeny of novel Trichoderma isolates from mangrove sediments and potential of biocontrol against Fusarium Strains. Microb Cell Fact 18: 89. DOI: 10.1186/s12934-019-1108-y

Gálvez L, Sandra, Loiseau G, Paredes JL, Barel M, Guiraud JP. 2007. Study on the microflora and biochemistry of cocoa fermentation in the Dominican Republic. Int J Food Microbiol 114 (1): 124-30. DOI: 10.1016/j.ijfoodmicro.2006.10.041

Gullo M, La China S, Falcone PM, Giudici P. 2018. Biotechnological production of cellulose by acetic acid bacteria: current state and perspectives. Appl Microbiol Biotechnol 102 (16): 6885-6898. DOI: 10.1007/s00253-018-9164-5

Gul O, Atalar I, Mortas M, Dervisoglu M. 2018. Rheological, textural, colour and sensorial properties of kefir produced ith buffalo milk using kefir grains and starter culture: A comparison with cows' milk kefir. Int J Dairy Technol 71: 73-80. DOI: 10.1111/1471-0307.12503

Hotessa N, Jedala R. 2020. Ethiopian indigenous traditional fermented beverage: The role of the microorganisms toward nutritional and safety value of fermented beverage. Int J Microbiol 2020: 1-11. DOI: $10.1155 / 2020 / 8891259$

Hyun S, Lee J. 2014. Microbiological characteristics and physiological functionality of new records of yeasts from wildflowers in Yokjido, Korea. Mycobiol 42 (2): 198-202. DOI: 10.5941/myco.2014.42.2.198

Jayabalan R, Malbaša RV, Lončar ES, Vitas JS, Sathishkumar M. 2014. A review on Kombucha tea-microbiology, composition, fermentation, beneficial effects, toxicity, and tea fungus. Compr Rev Food Sci Food Saf 13: 538-550. DOI: 10.1111/1541-4337.12073

Jespersen L, Nielsen D, Hønholt S, Jakobsen M. 2005. Occurrence and diversity of yeasts involved in fermentation of West African cocoa beans. FEMS Yeast Res 5 (4-5): 441-453. DOI: 10.1016/j.femsyr.2004.11.002

Jimoh SO, Ado SA, Joseph BA, Clement MZW. 2012. Characteristics and diversity of yeast in locally fermented beverages sold in Nigeria. World J Eng Pure Appl Sci 2 (2): 40-44.

Karki TB, Parash MT, Archana Y, Gyanu RP, Yogesh J, Sahansila B, Rojina A, Katyayanee N. 2017. Selection and characterization of potential baker's yeast from indigenous resources of Nepal. Biotechnol Res Int 2017: 1-10. DOI: 10.1155/2017/1925820

Kim HJ, Lee H-R, Kim CS, Jin Y-S, Seo JH. 2013. Investigation of protein expression profiles of erythritol-producing Candida magnoliae in response to glucose perturbation. J Enzyme Microb Technol 53: 174-180. DOI: 10.1016/j.enzmictec.2013.03.016

Knop M. 2011. Yeast life cycles are complex and contain cellular stages involving many different forms and shapes of cells. Comptes Rendus Biologies 334: 599-606. DOI: 10.1016/j.crvi.2011.05.007

Kuhad RC, Gupta R, Singh A. 2011. Microbial cellulases and their industrial applications. Enzyme Res 2011 (1): 1-10. DOI: $10.4061 / 2011 / 280696$

Kumoro AC, Sari DR, Pinandita APP, Retnowati DS, Budiyati CS. 2012. Preparation of wine from jackfruit (Artocarpus heterophyllus Lam) juice using baker yeast: Effect of yeast and initial sugar concentrations. World Appl Sci J 16 (9): 1262-1268.

Loncar ES,Vitas J, Malbasa R, Grahovac J. 2013. The antioxidant activity of kombucha fermented milk products with stinging nettle and winter savory. Chem Ind Chem Eng Q 19 (1): 129-139. DOI: 10.2298/ciceq120205048v

Loncar ES, Katarina G, Kanuric RV, Mirjanna SD, Spansenija DM. 2014. Kinetics of saccharose fermentation by Kombucha. Chem Ind Chem Eng 20 (3): 345-352. DOI: 10.2298/ciceq1211130161

Mahulette F, Astuti DI. 2020. The optimization of the Ambonese arrack fermentation using co-culture Pichia polymorpha and Kloeckera 
javanica. Biodiversitas 21 (7): 2900-2906. DOI: 10.13057/biodiv/d210705

Marsh AJ, Orla O, Colin H, Ross RP, Paul DC. 2014. Sequence-based analysis of the bacterial and fungal compositions of multiple Kombucha (tea fungus) samples. Food Microbiol 38: 171-178. DOI: 10.1016/j.fm.2013.09.003

May AN, James M, Joe A, Carlo M, Athena A. 2017. Kombucha as a model system for multispecies microbial cooperation: Theoretical promise, methodological challenges and new solutions 'in solution'. Biorxiv 214478. DOI: $10.1101 / 214478$

Medeiros ASS. 2014. Fermentation of fruit juices by the osmotolerant yeast Candida magnoliae. [Dissertation]. Universidade Nova de Lisboa, Lisboa. [Portugal]

Mills DA, Johannsen EA, Cocolin L. 2002. Yeast diversity and persistence in botrytis-affected wine fermentations. Appl Environ Microbiol 68 (10): 4884-4893. DOI: 10.1128/aem.68.10.4884-4893.2002

Mukadam TA, Kapil P, Sunita DD, Shashikant PV, Abhay SC. 2016. Isolation and characterization of bacteria and Yeast from Kombucha tea. Int J Curr Microbiol Appl Sci 5 (6): 32-41. DOI: 10.20546/ijcmas.2016.507.002

Neffe-Skocińska K, Sionek B, Ścibisz I, Kołożyn-Krajewska D. 2017. Acid contents and the effect of fermentation condition of Kombucha tea beverages on physicochemical, microbiological and sensory $\begin{array}{lllll}\text { properties. J Food } 15 & \text { (4): 601-607. DOI }\end{array}$ 10.1080/19476337.2017.1321588

Nurhayati N, Bambang S, Ika F, Jayus J. 2018. Isolation and identification of osmophilic yeasts isolated from molasses sugarcane as bioethano starter. Adv Eng Res 172: 223-228. DOI: 10.2991/fanres-18.2018.46

Nursiwi A, Ishartani D, Sari AM, Nisyah K. 2018. Study on Leucaena leocochepala seed during fermentation: sensory characteristic and changes on anti nutritional compounds and mimosine level. In IOP Conf Ser: Earth Environ Sci 102 (1): 012093). IOP Publishing. DOI: 10.1088/1755-1315/102/1/012093

Pratiwi A, Aryawati R. 2012. Pengaruh waktu fermentasi terhadap sifat fisik dan kimia pada pembuatan minuman kombucha dari rumput laut Sargasssum sp. Maspari J: Mar Sci Res 4 (1): 131-136. [Indonesian]

Quiao-Won ME, Franco GT. 2018. Characteristics of Kombucha fermentation from different substrates and cytotoxicity of tea broth. $J$ Sustain Food Prod 4: 11-19. DOI: 10.18052/www.scipress.com/sfp.4.11

Rahman SA, Nurmiati, Periadnadi. 2018. The presence of natural microflora in tapai fluid of cassava (Manihot Utilissima Pohl.) from traditional market in Padang. World J Pharm Life Sci 4 (8): 15-20.

Rizal S, Suharyono, Fibra N, Julfi RA. 2020. The effects of lowtemperature storage on the viability of Lactobacillus casei and the stability of antibacterial activity in green grass jelly synbiotic drinks. Biodiversitas 21 (8): 3826-3831. DOI: 10.13057/biodiv/d210851

Rosca I, Anca RP, Mihai B, Irina S, Bogdan M, Narcisa M. 2015. An original method for producing acetaldehyde and diacetyl by Yeast fermentation. Braz J Microbiol 47: 949-954. DOI 10.1016/j.bjm.2016.07.005

Santra T, Ghosh SK, Chakravarty A. 2014. Different methods for DNA extraction from yeast-candida famata isolated from Toddy. $\mathrm{Br}$ Biotechnol J 4 (1): 64-73. DOI: 10.9734/bbj/2014/4884
Sawab A, Hanan MA, Mayasem A. 2017. Pharmacognostic studies on Coffee arabica L. Husks: A brilliant source of antioxidant agents. Eur J Pharm Med Res 4 (1): 86-92

Senne OL, Felipe, Bajic D, Vila JCC, Sánchez A, Sommer MOA. 2021. Complex yeast-bacteria interactions affect the yield of industrial ethanol fermentation. Nat Comm 12 (1): 1-12. DOI: 10.1038/s41467021-21844-7

Tomovska J, Nikola G, Borche M. 2016. Examination of pH, titratable acidity and antioxidant activity in fermented milk. J Mater Sci Eng 6 (11): 326-333. DOI: 10.17265/2161-6213/2016.11-12.006

Tran T, Grandvalet C, Verdier F, Martin A, Alexandre H, Tourdot-Maréchal R. 2020. Microbiological and technological parameters impacting the chemical composition and sensory quality of kombucha. Compr Rev Food Sci Food Saf 19 (4): 2050-2070. DOI: $10.1111 / 1541-4337.12574$

Tran T, Cosette G, François V, Antoine M, Hervé A, Raphaëlle T. 2020. Microbial dynamics between yeasts and acetic acid bacteria in Kombucha: Impacts on the chemical composition of the beverage. Foods 9 (7): 963. DOI: 10.3390/foods9070963

Valencia PE, Meitiniarti VI. 2017. Isolasi dan karakterisasi jamur ligninolitik serta perbandingan kemampuannya dalam biodelignifikasi. Scripta Biologica 4 (3): 171-175. DOI: 10.20884/1.sb.2017.4.3.449 [Indonesian]

Villarreal-Soto SA, Beaufort S, Bouajila J, Souchard J-P, Taillandier P. 2018. Understanding kombucha tea fermentation: A review. J Food Sci 83 (3): 580-588. DOI: 10.1111/1750-3841.14068

Villarreal-Soto SA, Jalloul B, Mauro P, John L, Paul DC, Jean-Pierre S, Patricia T, Sandra B. 2020. Metabolome-microbiome signatures in the fermented beverage, Kombucha. Int J Food Microbiol 333: 108778. DOI: 10.1016/j.ijfoodmicro.2020.108778

Wistiana, Duwi, Zubaidah E. 2015. Karakteristik kimiawi dan mikrobiologis kombucha dari berbagai daun tinggi fenol selama fermentasi. Jurnal Pangan dan Agro Industri 3 (4): 1446-1457. [Indonesian]

Yadav JSS, Bezawada J, Yan S, Tyagi RD, Surampalli RY. 2012. Candida krusei: Biotechnological potentials and concerns about its safety. Can J Microbiol 58 (8): 937-952. DOI: 10.1139/w2012-077

Yaoa W, Xiao W, Jun Z, Bo S, Yan YZ, Curtis M. 2011. Bacterial cellulose membrane-A new support carrier for yeast immobilization for ethanol fermentation. Process Biochem 46: 2054-2058. DOI: 10.1016/j.procbio.2011.07.006

Yu J-H, Lee D-H, Park Y-C, Lee M-G, Kim D-O, Ryu Y-W, Seo J-H. 2008. Proteomic analysis of fructophilic properties of osmotolerant Candida magnoliae. J Microbiol Biotechnol 18 (2): 248-254.

Yusuf D, Lilis N, Ratih DH, Dase H. 2020. Lactic acid bacteria and yeasts from Indonesian kefir grains and their growth interaction. Asian $\mathrm{J}$ Microbiol Biotechnol Environ Sci 22 (1): 44-49.

Ziaee A, Mohammadali Z, Mansour B, Jamal H. 2016. Molecular identification of Mucor and Lichtheimia species in pure cultures of Zygomycetes. Jundishapur J Microbiol 9 (4): e35237. DOI: $10.5812 \% 2$ Fjjm. 35237

Zou Y, Zou B, Yu YS, Xu YJ, Wu JJ, Xiao GS, Fu MQ. 2019. Effect of fermentation by co-culture of yeast and lactic acid bacterium on the quality of lychee juice. Mod Food Sci Technol 35 (10): 189-195. DOI: $10.13982 /$ j.mfst.1673-9078.2019.10.026 